$10: 11 \sim 13,1998$

\title{
Endolaryngeal Microsurgery Using a Video-laryngoscope
}

\author{
Kuniyoshi Tsuda, Seiji Takagi and Takemoto Shin \\ ビデオラリンゴスコープによる喉頭微細手術
}

\begin{abstract}
津 田邦良, 高木誠治, 進武幹
ラリンゴマイクロサージャリーは 1960 年代から喉頭の微細手術手技として広く用いられている. 今回我々 は近年開発されたビデオラリンゴスコープを用いた喉頭内微細手術法をこれまで用いられてきたいわゆるラ リンゴマイクロサージャリーと比較検討した。その結果以下の点においてビデオラリンゴが優れていること が判明した。

1 ）広い術野が得られる。2）細径の喉頭鏡を用いるため挿入とその後の固定が容易である．３）従来の顕 微鏡を使用しないため双手で手術器具を操作する際に自由な空間が得られる.
\end{abstract}

Key words : Video-laryngoscope, endolaryngeal microsurgery, larynx

\section{Introduction}

Beginning with the work of Kleinsasser et al. in the 1960s, endolaryngeal microsurgery (LMS) has become widely accepted as a routine procedure for microsurgery of the laryn $x^{1)}$. With the cooperation of surgeons and anesthesiologists, continual improvements in the instruments and methodologies have contributed to even wider acceptance of this procedure. These developments, in conjunction with the introduction of the $\mathrm{CO}_{2}$ laser by Strong ${ }^{2)}$ and Jako $^{3)}$ during the 1970s, have widened the range of diseases that can be treated using this procedure. Now, LMS is an important diagnostic and surgical tool for phonosurgery and the treatment of laryngeal cancer.

We introduced VLS in 1995. Now we use both LMS and VLS in laryngeal microsurgery. Based on our experience, we decided to compare LMS and VLS. In 1991, Kantor et al. ${ }^{4,5)}$ reported the clinical usefulness of the then newly-developed endolaryngeal microsurgery technique which employs a video-laryngoscope and is often referred to as video laryngeal microsurgery (VLS).

\section{Patients and methods}

Three cases of vocal cord polyps and one case of polypoid vocal cord were used for comparison. For LMS procedures we used a Karl-Zeiss operating microscope. For VLS procedures we used a Karl Storz

佐賀医科大学耳鼻咽喉科学教室

Department of Otolaryngology, Saga Medical School
Kantor-Berci Video-Laryngoscope Model II . A detachable, forward-viewing telescope was integrated into the laryngoscope (Fig. 1) at the 12 o'clock position. The eye piece is angled at $45^{\circ}$ to allow for direct viewing as well as attachment of the Karl Storz Endovision Tricam camera to the laryngoscope. The telescope lens is positioned at the distal tip and provides $15^{\circ}$ viewing angle. It allows visualization of the anterior region.

Comparison of LMS and VLS was based on the following five features: (1) field of view, (2) ease of insertion and suspension access/approach, (3) working space for manipulation of instruments, (4) visibility area, and (5) instrument maintenance.

Results

\section{Field of view}

VLS using a 26-mm video-laryngoscope allowed a somewhat wider view of the polypoid vocal cord (Fig. 2) when compared to LMS using a $32-\mathrm{mm}$ laryngoscope for the same polypoid vocal cord (Fig. 3 ). The wider view was particularly marked in the anterior region. The field of a view depend on the capacity of the telescope regardless of the laryngoscope.

2. Ease of insertion and suspension access/approach In VLS the lens of the telescope is simply, positioned closer to the tissue being viewed than in LMS. This allows for use of narrower laryngoscopes and makes access to the larynx easier. In VLS the laryn- 


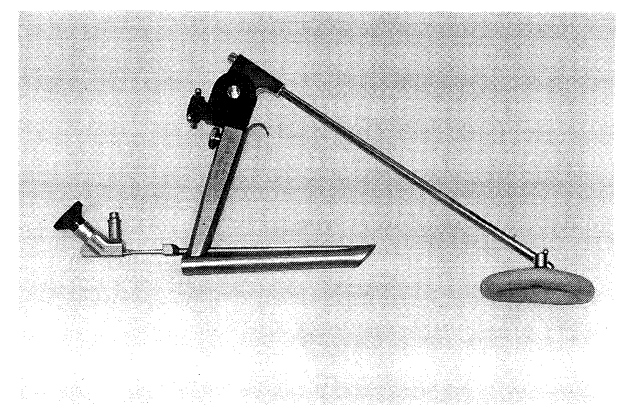

Fig. 1 Forward-viewing telescope was integrated into the laryngoscope at the 12 o'clock position.

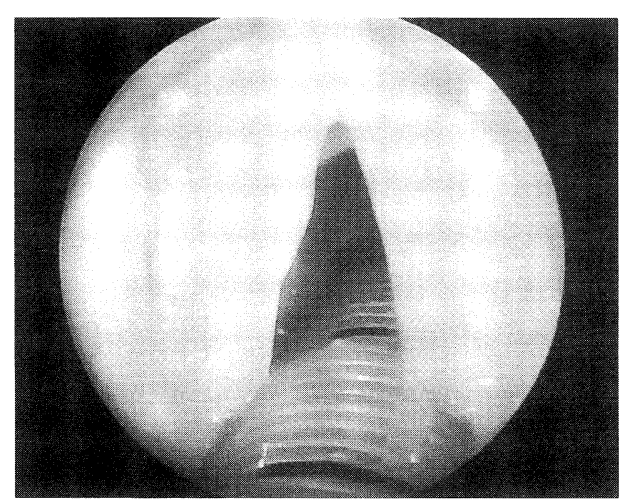

Fig. 2 VLS using allowed a somewhat wider view of the polypoid vocal cord.

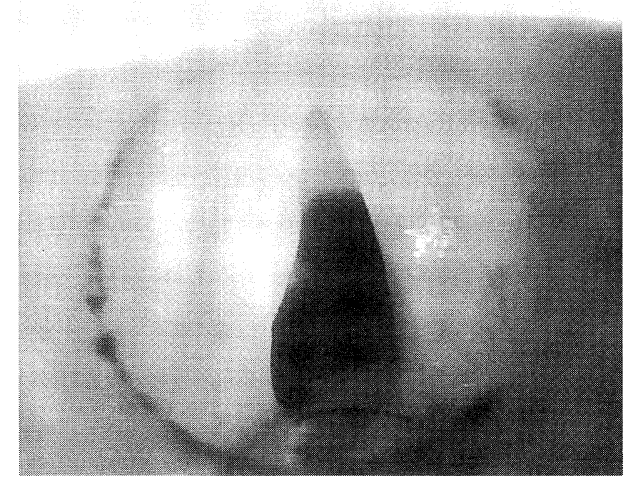

Fig. 3 The view of the same polypoid vocal cord with LMS.

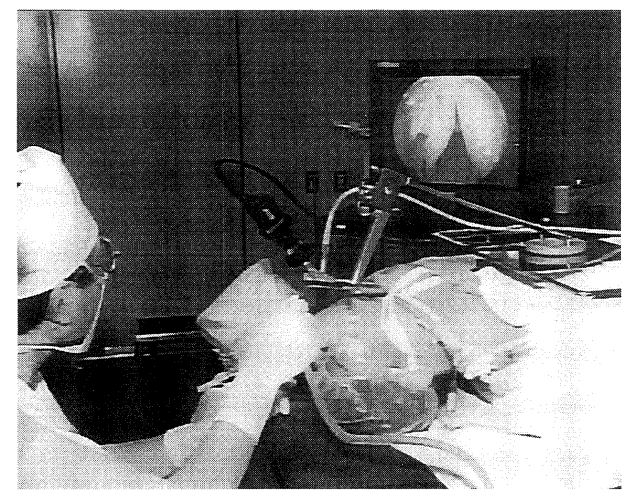

Fig. 4 All the inner space of the laryngoscope is available for working space with VLS.

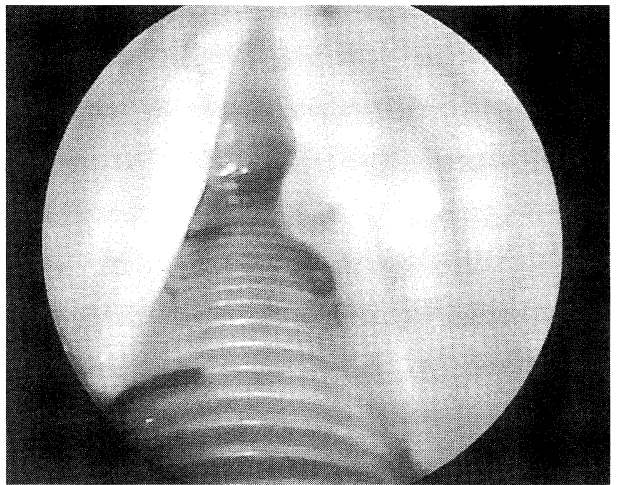

Fig. 5 A view of vocal cord polyp with VLS

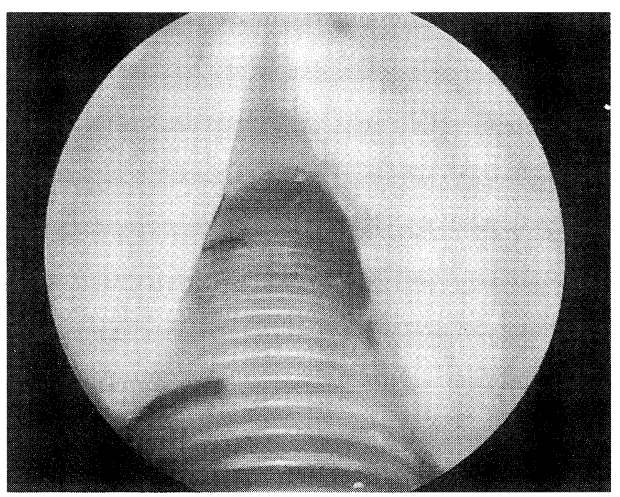

Fig. 6 Post operative view using VLS

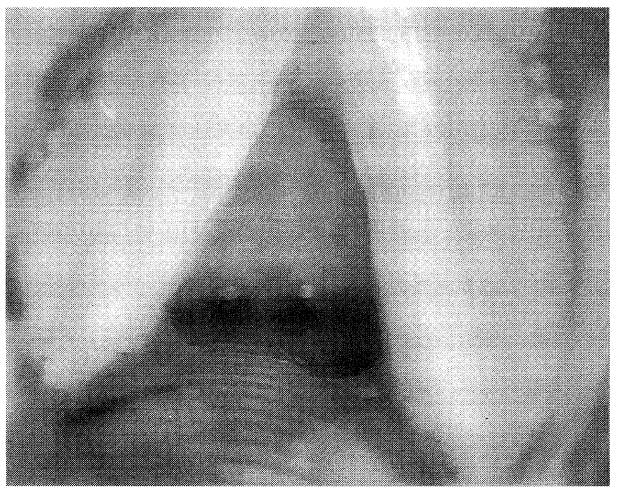

Fig. 7 Post operative view using LMS

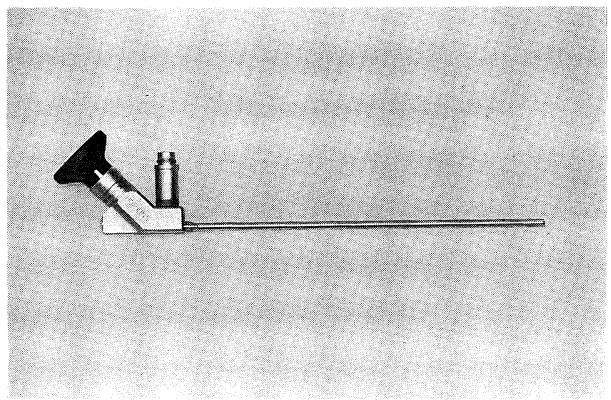

Fig. 8 The telescope lens is positioned at the distal tip and provides $15^{\circ}$ viewing angle. 
goscope is available in two sizes widths, $21-\mathrm{mm}$ and 26-mm.

3. Working space for instrumentation

In some cases, manipulation of the forceps and suction tubes can be difficult using LMS because the instruments obstruct the field of view. With VLS, all the inner space of the laryngoscope is available for working (Fig. 4). VLS provides for unobstructed bimanual manipulation of the instruments.

\section{Area Visibility}

VLS facilitates a somewhat enlarged view in comparison to LMS. A comparison of Fig. 2 and Fig. 3 illustrates this increase in visibility. Fig. 5 shows a vocal cord polyp as viewed through the Videolaryngoscope prior to surgery. Fig. 6 shows the same area post-operatively, while Fig. 7 shows the area post-operatively using the LMS microscope.

5. Instrument maintenance

Unlike the standard laryngoscopes used in LMS, video-laryngoscopes integrate a detachable telescope and the standard laryngoscope. The telescope can be damaged if impacted or dropped. Care must be taken during handling and storage of the optical telescope (Fig. 8).

\section{Discussion}

In VLS, the field of view is wider than in LMS, in spite of using a narrower laryngoscope. VLS is more especially when visual access to the anterior region is needed.

However, VLS in our cases produced a slightly curved picture of the free edge of the vocal cords despite a straight cut along the free edge. We believe that this is caused by the new position of the telescope lens and the resulting shift of the eye's viewing point associated with the VLS device. However, surgery is not disturbed by this distortion of the pictures.
Sometimes access can be difficult when the patient has a stiff neck, a large tongue, or a narrow laryngeal space. In such cases, the VLS forward-viewing telescope and the narrower $21-\mathrm{mm}$ and $26-\mathrm{mm}$ videolaryngoscopes make access much easier.

Finally, the most important benefit of VLS is the creation of an unobstructed working space. The telescope lens in VLS is quite close to the tissue being examined, which prevents the surgeons hands or instruments from obstructing the view. This is the critical difference between VLS and LMS. However, even if the these advances make laryngeal microsurgery easier for the inexperienced surgeon, we recommend VLS only for the surgeon with solid training in LMS.

\section{References}

1) Kleinsasser $O:$ Weitere technische entwicklung und erste ergebnisse der endolarungealen mikrochirugie. Z Laryng Rhinl Otol 44 : 711 727, 1965.

2) Strong MS \& Jako GJ : Laser surgery in the larynx. Early clinical experience with continuous $\mathrm{CO}_{2}$ laser. Ann Otol Rhinol Laryngol 81 : 791 798, 1972.

3) Jako GJ : Laser surgery of the vocal cords. An experimental study with carbon dioxide laser on dogs. Laryngoscope 82:2204 2216, 1972.

4) Edward K : A completely new approach to microlaryngeal surgery. Laryngoscope 101 : 676 679, 1991.

5) Edward $\mathrm{K}$ : Ancillary instruments for the video microlaryngoscope. Ann Otol Rhinol Laryngol $100: 317 \sim 319,1991$.

別刷請求先 $\quad$ \% 849-8501 佐賀市鍋島5-1-1 佐賀医科大学耳鼻咽喉科学教室 津田邦良 